\title{
The Impact of Tariff Reforms on Income Distribution in Pakistan: A CGE-based Analysis
}

\author{
REHANA SIDDIQUI, RIZWANA SIDDIQUI, and ZAFAR IQBAL
}

\section{INTRODUCTION}

Like most developing countries, Pakistan has undertaken drastic economic policy reforms since the mid-1980s. Under these structural reforms there is a general shift away from quantitative restrictions and price controls towards liberalisation and privatisation. The empirical studies ${ }^{1}$ analysing the impact of the reforms report mixed results. Economy wide framework like Computable General Equilibrium (CGE), based on the social accounting matrix, is well suited to analysing the effect of these structural reforms. The CGE models are developed to capture the medium to long-run effects through which adjustment programmes affect income distribution. These models are often used to evaluate the effects of trade and tax policies on income distribution in developing countries. There are three interacting channels through which these adjustment policies affect income distribution, viz., the relative price effect, the asset price effect and the shift in portfolio. However, in this study, we are analysing the effect of changes in relative prices only.

The first and more easily quantifiable channel is through analysis of the impact of changes in production prices following changes in tariff. For a given shock in the above mentioned policy variables, the medium to long-run distributional impact of the resulting structural adjustment is determined by the extent of relative price rigidities (fixed real wages, or mark up pricing), the extent of factor mobility (supply elasticity's) and difference in consumption pattern across socio-economic groups. Difference in assumptions and closure rule play a very important role in market adjustment mechanism in developing countries. Simulation exercises show that assumptions about the macro economic closure and behavioural parameters matter a great deal in determining the productive and distributive effects of a shock and a country's adjustment to the shock. These exercises also show the channels through

Rehana Siddiqui and Rizwana Siddiqui are Senior Research Economist and Staff Economist at the Pakistan Institute of Development Economics, Islamabad. Zafar Iqbal is working as Economist at the Office of the Senior Resident Representative, International Monetary Fund, Islamabad.

${ }^{1}$ See Amjad and Kemal (1997); White (1997); Tilat (1996); Mahmood (1999); Iqbal and Siddiqui (1999); Siddiqui and Iqbal (1999a) and Thorbeck (1991). 
which a country can capture the effects of alternative adjustment packages on income distribution. For example, resistance to wage cut and profit cut has strong implications for the factoral distribution of income. Poverty is likely to increase when there is resistance because the economy is not functioning at full capacity. Utilising the framework developed by Decaluwe et al. (1999) and Siddiqui and Iqbal (1999a), the study is extended in the following way. Households are disaggregated by regions (i.e., by urban/rural) and by income groups to see the impact of tariff rate reduction on imported goods on income distribution. The order of the study is as follows: Model is discussed in Section 2 and results are discussed in Section 3. Conclusions are in the final section.

\section{MODEL}

The general structure of "Micro-Macro" economy-wide simulation model is used to analyse the impact of tariff reduction on distribution of income. Trade tax reforms (tariff reduction) affect the pattern of sectoral demand and it can be well captured by the disaggregation of production sector through the CGE model.

\section{(a) Structure of SAM 1989-90 for Pakistan}

Every economy-wide model, particularly the CGE model, requires a consistent database. For this paper data arranged in Social Accounting Matrix (SAM) framework provides the best consistent data set. For Pakistan, the latest SAM for the year 1989-90 is given in Siddiqui and Iqbal (1999) (see Table 1). It presents a comprehensive picture of the whole economy. It disaggregates production activities into five sectors; agriculture, industry, education, health and others. These commodities are then transformed into traded goods, i.e., exportable, and non-traded goods, i.e., goods for the domestic market. This disaggregation allows us to capture the effects of policy changes on sectoral demands and supplies. Factors of production are disaggregated into labour and capital. Four types of institutions are identified as households, firms, government and rest of the world. ${ }^{2}$ In accordance with the orientation of analytical interest and policy problems related with the field of distribution of income and consumption, classifications in the SAM-1989-90 (in the present form) highlights the income receipt pattern of aggregate households from different sources and their uses on different items and household sector is disaggregated by region, rural and urban areas of Pakistan. In each region households are categorised by four income groups; upto

\footnotetext{
${ }^{2}$ We distinguished household group in our earlier study [Siddiqui and Iqbal (1999)] into four income groups for rural and urban areas of Pakistan separately. This disaggregation is carried out to make an example how the SAM framework and the related CGE model can combine the macro economic features with microeconomic issues. Although disaggregation of the household sector is of much importance to see the impact on income distribution, but in this paper we just keep the household sector aggregate.
} 
Table 1

Simulation Results with $10 \%$ Reduction in Tariff Rate on Industrial Imports

\begin{tabular}{|c|c|c|c|c|c|c|c|c|c|c|}
\hline Variables & \multicolumn{3}{|c|}{ Base Year } & \multicolumn{2}{|c|}{ Percentage Change } & $\begin{array}{l}\text { Variables } \\
\end{array}$ & \multicolumn{2}{|r|}{ Base Year } & \multicolumn{2}{|c|}{ Percentage Change } \\
\hline $\begin{array}{l}\mathrm{VA}_{\mathrm{ag}} \\
\mathrm{n}\end{array}$ & \multirow{2}{*}{\multicolumn{3}{|c|}{212693}} & \multicolumn{2}{|c|}{0.55} & \multirow{2}{*}{$\begin{array}{l}\mathrm{XS}_{\mathrm{ag}} \\
\mathrm{XS}_{\mathrm{ag}}\end{array}$} & \multirow{2}{*}{\multicolumn{2}{|c|}{$\begin{array}{l}355811 \\
630627\end{array}$}} & \multicolumn{2}{|c|}{0.55} \\
\hline $\mathrm{VA}_{\text {ind }}$ & & & & \multicolumn{2}{|c|}{-0.76} & & & & \multicolumn{2}{|c|}{-0.76} \\
\hline $\mathrm{VA}_{\mathrm{he}}$ & \multicolumn{3}{|c|}{$\begin{array}{c}150037 \\
5963\end{array}$} & \multicolumn{2}{|c|}{2.63} & $\begin{array}{l}\mathrm{XS}_{\text {ind }} \\
\mathrm{XS}_{\text {S }}\end{array}$ & \multicolumn{2}{|r|}{$\begin{array}{l}00021 \\
8919\end{array}$} & \multicolumn{2}{|c|}{2.63} \\
\hline $\mathrm{VA}_{0}$ & \multicolumn{3}{|c|}{$\begin{array}{c}5963 \\
361752\end{array}$} & \multicolumn{2}{|c|}{-0.20} & XS & & \multicolumn{2}{|c|}{-0.20} \\
\hline \multirow[t]{4}{*}{$\mathrm{VA}_{\mathrm{ed}}$} & \multicolumn{3}{|c|}{17332} & \multirow{2}{*}{\multicolumn{3}{|c|}{$\begin{array}{c}3.13 \\
\text { Percentage Change in Household Demand for Good }\end{array}$}} & \multicolumn{2}{|r|}{$\begin{array}{c}620705 \\
19044\end{array}$} & 3.1 & \\
\hline & & & & & & & \multicolumn{2}{|r|}{19044} & & \\
\hline & & ilture & & stry & & alth & & Others & & cation \\
\hline & Base value & $\begin{array}{l}\%-\text { age } \\
\text { change }\end{array}$ & Base value & $\%$-age change & Base value & $\%$-age change & Base value & \%-age change & Base value & $\begin{array}{l}\% \text {-age } \\
\text { change }\end{array}$ \\
\hline $\mathrm{CH}_{\mathrm{ul}}$ & 25837 & 0.50 & 33485 & 8.57 & 556 & 0.60 & 17820 & 3.29 & 406 & 0.31 \\
\hline $\mathrm{CH}_{\mathrm{u} 2}$ & 27784 & 0.71 & 36436 & 8.79 & 606 & 0.81 & 21677 & 3.50 & 742 & 0.52 \\
\hline $\mathrm{CH}_{\mathrm{u} 3}$ & 24995 & 0.93 & 34039 & 9.02 & 637 & 1.03 & 22181 & 3.73 & 851 & 0.74 \\
\hline $\mathrm{CH}_{\mathrm{u} 4}$ & 16085 & 1.32 & 23174 & 9.45 & 327 & 1.42 & 24415 & 4.13 & 1363 & 1.13 \\
\hline $\mathrm{CH}_{\mathrm{rl}}$ & 47929 & 0.82 & 59768 & 8.90 & 1004 & 0.92 & 24758 & 3.61 & 404 & 0.62 \\
\hline $\mathrm{CH}_{\mathrm{r} 2}$ & 28600 & 1.13 & 35334 & 9.24 & 594 & 1.23 & 16347 & 3.93 & 366 & 0.94 \\
\hline $\mathrm{CH}_{\mathrm{r} 3}$ & 22050 & 1.22 & 28120 & 9.35 & 549 & 1.32 & 14642 & 4.03 & 337 & 1.03 \\
\hline $\mathrm{CH}_{\mathrm{r} 4}$ & 10618 & 1.33 & 13805 & 9.46 & 276 & 1.43 & 9166 & 4.14 & 204 & 1.14 \\
\hline INV & 1458 & -22.34 & 96225 & -16.11 & 14 & -22.26 & 65348 & -20.18 & 7.0 & -22.48 \\
\hline & & & & & Labour Dema & & & & & \\
\hline $\mathrm{L}_{\mathrm{D}}$ & 45681 & -4.76 & 45415 & 1.07 & 2839 & 1.03 & 101471 & 1.38 & 13883 & 1.90 \\
\hline & & & & Perce & atage Change & Prices & & & & \\
\hline & Base value & $\%$-age change & Base value & $\begin{array}{l}\% \text {-age } \\
\text { change }\end{array}$ & Base value & $\%$-age change & Base value & $\%$-age change & Base value & $\%$-age change \\
\hline $\mathrm{W}^{*}$ & 209289 & -4.81 & & & & & & & & \\
\hline$P_{D}$ & 1.0 & & 1.0 & -9.10 & 1.0 & -4.15 & 1.0 & -6.90 & & \\
\hline $\begin{array}{l}\mathrm{D} \\
\mathrm{P}\end{array}$ & $\begin{array}{l}1.0 \\
1.0\end{array}$ & -4.10 & $\begin{array}{l}1.0 \\
1.0\end{array}$ & $\begin{array}{l}-9.10 \\
-7.64\end{array}$ & $\begin{array}{l}1.0 \\
1.0\end{array}$ & -4.15 & 1.0 & $\begin{array}{l}-0.90 \\
-6.53\end{array}$ & $\begin{array}{l}1.0 \\
1.0\end{array}$ & -3.82 \\
\hline $\mathrm{P}_{\mathrm{VA}_{\mathrm{A}}}$ & 1.0 & -2.24 & 1.0 & -5.93 & 1.0 & -1.41 & 1.0 & -4.68 & 1.0 & -3.45 \\
\hline$P_{c}$ & 1.0 & -4.00 & 1.0 & -11.16 & 1.0 & -4.10 & 1.0 & -6.59 & 1.0 & -3.82 \\
\hline $\mathrm{P}_{\mathrm{M}}$ & 1.0 & 0.0 & 1.0 & -16.37 & 1.0 & 0.0 & 1.0 & 0.0 & 1.0 & 0.0 \\
\hline $\mathrm{P}_{\mathrm{E}}$ & 1.0 & 0.0 & 1.0 & 0.00 & 1.0 & 0.0 & 1.0 & 0.0 & 1.0 & 0.0 \\
\hline $\mathrm{P}^{*}{ }^{*}{ }_{\text {index }}$ & 1.0 & -6.39 & & & & & & & & \\
\hline $\mathrm{R}$ & 1.0 & -1.70 & 1.0 & -2.41 & 1.0 & 1.19 & 1.0 & -3.58 & 1.0 & -0.36 \\
\hline
\end{tabular}


Table $1-$ (Continued $)$

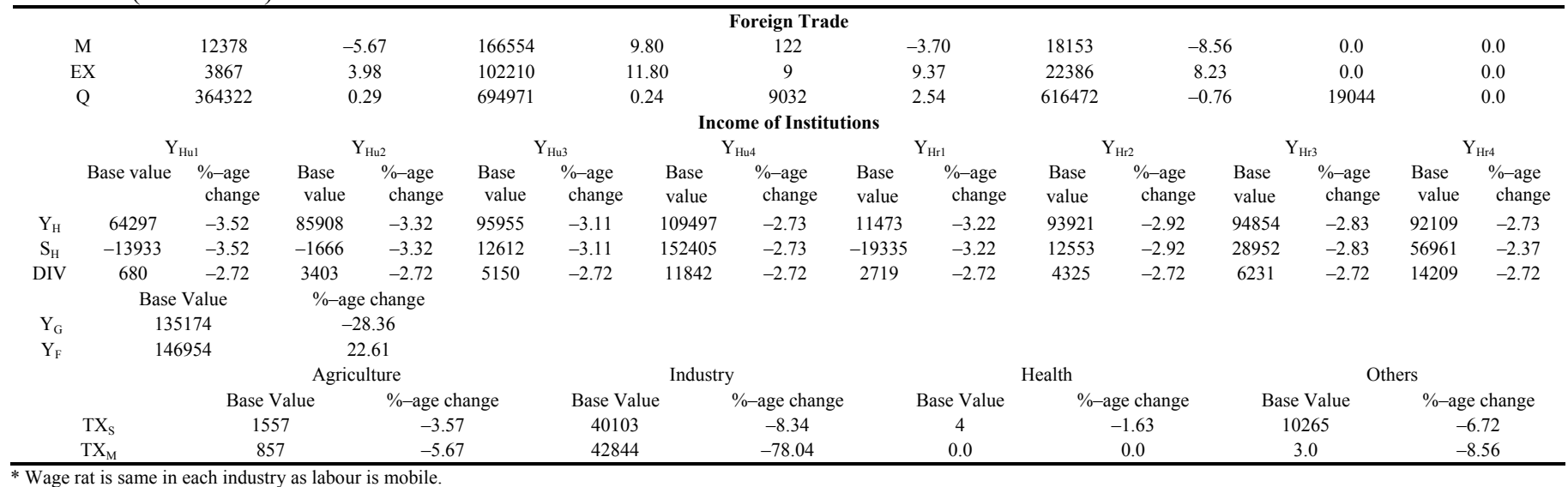

* Wage rat is same in each industry as labour is mobile. 
Rs 2500, Rs 2501-4000, Rs 4001-7000, and Rs 7001 and above. The mechanism by which policy changes affect the distribution of income are as follows:

(a) Changes in factor rewards directly affect household income distribution.

(b) Changes in relative production prices affect real income of households differently as baskets of consumption goods differ by income group.

The following issues determine the outcome of policy change:

(1) The selection of macroeconomic closure rule and institutional characteristics (assumption about the working of markets) affect the distributional outcome of policy change. The simulation exercise shows how important closure rule and institutional settings are to the distributive consequences of a shock. Since the outcome of policy change varies with institutional characteristics, the selection of adjustment policy is critical.

(2) Sector specific supply of capital stock is fixed. Increase (decrease) in demand change the price of capital, not the allocation.

(3) Decline in prices due to reduction in tariff has important implications for resource allocation, income distribution and poverty alleviation.

\section{(b) Computable General Equilibrium Model for Pakistan}

The CGE Model is, basically neoclassical in nature, in line with the framework given in Decaluwe et al. (1996). The model contains six blocks with more than 200 equations. The exchange rate acts as numeraire. Its value is set equal to one. The mathematical equations of the model are given in Appendix. The theoretical background of the equations in each block of the CGE model are discussed below:

1. Production Sector: Domestic production is disaggregated into five sectors, viz., agriculture, industry, others, health and education. Like other empirical studies, we adopted technology in which gross output has separable production function. We assume the Cobb-Douglas production functions for value added and the Leontief technology between intermediate and value added and also within intermediates. Equations for gross output, value added (specified as a function of labour(L) and capital(K)) and intermediate demand (aggregate as well as disaggregated) are specified in Equations 1 to 4.

2. Factors' Demand: Assuming perfect competition and market clearing, labour demand function for the $i$ th sector is derived from respective Cobb-Douglas production function. Labour demand is specified in Equation 5. Capital is sector specific and it is assumed to be given in the short run. The price of capital is determined by Equation 30 in the price block. Changes in factor prices play important role in explaining the issue of functional income distribution.

3. Foreign Trade Sector: We assume that domestic sales and exports with the same sectoral classification represent goods of different qualities. The CET 
function describes the possible shift of sectoral production between the domestic and external markets. For import function, we assume that domestically produced goods sold in the domestic market are an imperfect substitute of imports (Armington assumption). Constant Elasticity of Substitution (CES) import aggregation function presents demand for composite goods (imported and domestically produced goods). In addition to Equation 6 for export transformation and Equation 7 for import aggregation, profit maximisation/cost minimisation gives desired exports and imports ratios as a function of relative prices (domestic to foreign prices). (see Equations 8 and 9, respectively.)

4. Income, Saving and Consumption: Institutions; households, firms, government, and rest of the world, receive income from five sources. Each institution has various sources of income. The endowment of primary factors and their rental values determine the institutions' income. All income and saving of institutions are used for consumption and investment purposes. Relevant equations are given in the income and saving block of the model.

(i) Household: All wage income accrues to households. Similarly households receive share of capital income (lambda) from total capital income from different activities. They also receive income from firms as dividends, transfers from government as social security benefits, and transfers from the rest of the world. Equation 12 represents total income of $\mathrm{h}^{\text {th }}$ households from the above mentioned sources. Dividends for the $\mathrm{h}^{\text {th }}$ households are determined by Equation 14. Transfers from the government and from the rest of the world are assumed to be exogenous. Households pay taxes to government. Subtracting taxes from the total income we get the disposable income of households. The consumption of $i$ th commodity by $\mathrm{h}^{\text {th }}$ households is defined by Equation 24, while total consumption of households is presented by Equation 25 . These equations describe how households' income is allocated among different goods. It is defined with fixed value share of $i$ th $\operatorname{good} \beta i j^{c}$. The sum of $\beta i j^{c}$ is equal to 1. In addition, savings of the $\mathrm{h}^{\text {th }}$ households is defined in Equation 15.

(ii) Firms: Firms receive income from capital and transfers from government. Equation 17 presents their total income. Income from capital (retained profit) is presented in Equation 16. Transfers from the government are given exogenously. Their expenditure includes tax payments to the government, dividends to $j$ th households, and transfers to the rest of the world, while the residual is saved by the firms.

(iii) Government: The third institution, government, receives income from the following sources, i.e., direct taxes (income tax from households, corporate taxes from firms), indirect taxes (from production sector), 
import duties, export duties, and transfers from the rest of the world. Total government revenue is given by Equation 22. Equations for indirect taxes, taxes from imports and from exports are presented in Equations 19, 20, and 21, respectively. Government's total current expenditure is given in value. Government's total expenditure on commodity ' $\mathrm{i}$ ' is the fixed share calculated through Equation 27. Government saving is calculated as a residual after subtracting consumption expenditure from total revenue.

The total consumption expenditure on goods $i$ is the sum of expenditure on goods ' $i$ ' by different household groups and by government. In addition to consumption expenditure, there is a demand for goods $i$ for the investment purposes. Equation 29 converts aggregate investment into demands for investment goods by sector of origin. $I$ is gross capital formation in commodity $i, \beta^{\mathrm{I}} i j$ is fixed value share where the sum of shares is equal to one. Gross saving from different households groups, firms, government and rest of the world serve as a source of funding for gross investment.

5. Prices: Block 5 of the model presents prices. There are seven different prices associated with each tradable good, as price of aggregate output, price of composite goods, price of domestic sale, domestic price of imports, domestic price of exports, world price of imports, and world price of exports. World prices of exports and imports are exogenously determined. All prices are defined in Equations 30 through 36. The price index i.e., GDP deflator, is presented in Equation 37.

6. Equilibrium: The final block presents saving investment equilibrium, goods market equilibrium, and labour market equilibrium by Equations 38, 39, and 40 , respectively.

7. Model Closure: The model is closed in the Current Account Balance equation and the exchange rate acts as numerair.

\section{RESULTS}

\section{(a) (i) Income Distribution by Sources of Income in Pakistan ${ }^{3}$ - Baseline Scenario}

In this paper households income from labour (wages and salaries), capital (operating surplus) and dividends (transfers from firms) are endogenously determined. Transfers from government and transfers from the rest of the world are exogenous. The results show how the income from different sources changes in response to policy change. ${ }^{4}$

The present study differs from Siddiqui and Iqbal (1999a) as households are distinguished by four income groups; (1) up to Rs 2500 per month (lowest), (2) Rs

${ }^{3}$ This part of the paper is taken from Siddiqui and Iqbal (1999).

${ }^{4}$ For details see Siddiqui and Iqbal (1999 a). 
2501-4000 (low), (3) Rs 4001-7000 (medium), and (4) Rs 7000 and above (high), for rural and urban areas of Pakistan. The study shows that 43.1 percent households are in the lowest income group. The second, third and fourth income groups, respectively, consist of 29.1 percent, 19.2 percent and 8.3 percent of total urban households of Pakistan. The study reports that the highest income group receives the highest percentage of total income, 31 percent and the lowest income group receives only 18 percent of total income. But on average one percentage of the lowest household receives only 0.42 percent while one percentage of households from high income group receives, on average, 3.7 percent of total income. This shows that the income of households from high income groups receive nine times higher than the income of lowest income group.

Labour supply is the main source of income of the poor in Pakistan, while the rich class earns the largest share of their income from capital and dividends. The study shows that 43.1 percent (lowest income households) receive 24.4 percent of total wages and salaries and 8.3 percent high income households receive 21.9 percent of total wages and salaries. As many as 48.4 percent of total households (both low and middle income groups) receive about 53.8 percent of total wages and salaries. The high income group receives the highest share of income from all other sources but wages, i.e., capital income ( 28.6 percent) and dividends from firms ( 56.2 percent). On the other hand, the lowest income group (but the highest percentage of households) receives the lowest share from the other sources of income, i.e. 17.6 percent as capital income and 3.2 percent as dividends from firms. Thus, it presents a clear picture of skewed income distribution by source in the urban areas of Pakistan.

The study shows that the main source of income of the poorest households is wages and salaries i.e. 54.2 percent of their total income comes from wages and salaries and 42.2 percent of their total income comes from capital and 1.1 percent as dividends from firms. The richest group of households earns 28.5 percent from wages and salaries and 40.1 percent from capital income. It is worth noting that in contrast to the lowest income group, the high income group receives the largest share from capital. The incomes of this group from other sources are also higher than the income of the lowest income group. It receives 11.6 percent of their total income from firms as dividends.

The study presents the percentage distribution of total income from different sources across the rural income groups and percentage of households' income from different sources. It shows that 59.8 percent of aggregate households in rural areas are in the lowest income group and only 4.5 percent households are in the high income group. This study also shows that in the poorest class, 60 percent of households receive 29.4 percent of total income and the rich, 4.5 percent of rural households receive 23.4 percent of total income. On average 1 percent rural poor households receive 0.49 percent of total income and one percent of high income groups receives 5.2 percent of total income. This shows that the income ratio between rich and poor in rural areas is 
10:1. The study also reveals that 51.2 percent of the total wages and salaries in rural areas is earned by households in the lowest income group. On the other hand, the high income group receives only 8.3 percent of total wages and salaries. Furthermore, we see that 25.9 percent of capital income accrues to the lowest income group (60 percent households) while 22.4 percent to the high income households (4.5 percent rural households). Similarly, the largest shares of dividend, i.e., 51.7 percent, from firms go to households in the high income group. The lowest income group receives only 9.9 percent of the total dividends from firms.

This study also shows that all income groups in rural areas earn the highest share of their income from capital. The lowest, low, middle and highest income groups receive 56.6 percent, 68.3 percent, 72 percent, and 61.5 percent of their income from capital respectively. It also shows that the lowest income group receives 37.4 percent of its total income and the highest income group 7.6 percent of its total income from wages and salaries. It is worth noting that as rural households' monthly income level increases, their percentage shares in dividends from firms also increases. These groups from the lowest to the highest income groups receive 2.6 percent, 5.2 percent, 7.4 percent and 17.1 percent of their respective income as dividends from firms, respectively. It is worth noting that shares of wages and salaries in households income fall as income rises and shares of income from capital and dividends increase as monthly incomes of rural households increase.

\section{(ii) Expenditure by Different Income Groups—Baseline Scenario}

In this model we endogenise household expenditure on individual commodities, total consumption and saving. But taxes paid by the households are exogenous. The consumption of agriculture products is basically food consumption, while consumption of manufacturing products is consumption of durable and nondurables like processed food items. As mentioned earlier, this baseline solution is discussed in Siddiqui and Iqbal (1999). The study shows that the share of each income gap in total expenditure on agriculture is 27.3 percent by the lowest income group and 17.0 percent by the highest income group in urban areas. The shares in total expenditures on manufacturing products are 18.2 percent and 26.3 percent for the high and the lowest income groups, respectively. The results shows expenditure on education is positively correlated with income. It is about 40.6 percent of total expenditure on education for the high income group and only 12.1 percent of total expenditure for the lowest income group. The order is reverse for expenditure on health as the lowest income group spends 26.2 percent and high income group spends only 15.4 percent of total expenditure on health. In Pakistan the tax system is progressive, so the highest share in total taxes $(37.2$ percent) is paid by the high income group. The lowest income group pays 7.3 percent of total taxes in urban areas. Similarly, households with high income contribute the lions' share to total households' saving and the low income group reports negative savings. 
The expenditure pattern of rural households reveals almost a similar expenditure pattern.

The study also discusses the pattern of expenditure within the rural income groups. It reveals that the lowest income group spends 45.9 percent of total expenditure on agriculture and 57.3 percent on manufactured commodities. As income rises the percentage expenditure of total expenditure on these commodities declines. The expenditures on agriculture commodities are 34.1 percent, 26.2 percent, and 12.8 percent of the total expenditure by the low, middle and high income groups, respectively. Similarly, expenditures on manufactured commodities are 42.2 percent, 33.4 percent, and 16 percent of total expenditure by the low, middle, and high income groups. Expenditure on education by all these income groups is less than 0.5 percent of their respective income. The same is the case for health expenditure by all income groups. The high income group pays 1.3 percent of its income as taxes to the government while the low, middle and high income groups pay less than 0.5 percent of their respective incomes as taxes to government. The lowest rural income group is a dissaver as 28.6 percent dissaving is reported by this group. The other three rural income groups save, respectively, 2.9 percent, 21.7 percent and 57.7 percent of their incomes. It is also worth noting that the high income group in rural areas saves 57.7 percent of its income as compared to the urban high income group, who saves 35.4 percent of its income.

\section{(b) Simulation Exercise: 80 Percent Reduction in Tariff Rate on Industrial Imports}

The impact of tariff rate reduction depends on the interaction between the domestic economy and the foreign trade sector. The first impact of reduction in tariff rate is lower import prices of industrial imports by 16.37. This decline in the imported price leads to increase in demand of imported goods and people substitute imports for domestically produced goods resulting in imports by 9.80 percent. As the demand for imported industrial goods increase and demand for domestically produced goods decline, domestic price of industrial goods also declines. Due to this decline in domestic price, producers reduces the supply of industrial goods by 0.76 percent. This reduction in production reduces the demand for factors of production. The demand for labour in this sector is reduced by 2.56 percent leading to decline in wages by 4.18 percent. Due to decline in wages the demand for labour in other sectors increases by 2.60 percent, 5.61 percent, and 3.93 percent in agriculture, health and education sectors, respectively. This leads to increase in production in these sectors. The prices of all these products also decline. The results show that returns to capital also decline. The decline in returns to factors of production leads to decline in income of institutions. 
The results also show that the income of each households group declines. The reduction in the income of the lowest income group is the largest. While the reduction in the income of the highest income groups is smallest in rural and urban areas of Pakistan. In short, the gap between the rich and poor is expected to increase after the shock.

Decline in prices leads to increase in demand of goods and services. The results show that the demand for industrial goods by each groups of households was the largest as compared to increase in demand for all other goods. The results also show that the increase in demand increases with the increase in income. This shows that the rich are benefiting more than the poor. The distributional impact of tariff reduction does not seem to be working in the right direction as the negative impact on household consumption is disproportionately high for lower income groups. As expected, the reduction in tariff results in significant loss of government revenue resulting in increase in public deficit and ultimate negative effect on capital formation.

\section{CONCLUSIONS}

The study examines the impact of reduction in tariff on industrial goods across households and on other broad macro aggregates. The simulation exercise suggests that the negative impact of changes in relative prices is disproportionately higher for the lower income groups. Thus, tariff reduction increases the gap between the rich and poor. Decline in investment also has negative implications for the economy as a whole. This paper suggest that income distribution is worsening in rural and urban areas of Pakistan due to reduction in tariff rate on industrial imports. We intend to extend this analysis by using more recent input-output table (whenever it becomes available). We will also compute 'gini' coefficient to complete the analysis.

Appendices

\section{Appendix 1}

\section{CGE MODEL FOR PAKISTAN}

\section{Production:}

(1) $X_{i}^{s}=\left(L, K, I C_{i}\right.$ io, $\left.V i\right)$ Production 5

(2) $V A_{i}=C D\left(K_{i}, L_{i}^{D} ; A, \alpha_{i}\right)$ Value Added 5

(3) $I C_{i}=L F^{*}\left(X_{i}^{S}\right)$ Intermediate Consumption of goods I 5

(4) $I C_{i j}=a_{i j}\left(I C_{j}\right)$ Intermediate Consumption of goods I in jth sector 25

(5) $L_{i}^{D}=C D^{*}\left(P_{i}^{V A} / W, V A_{i}\right)$ Labour Demand. 5

Foreign Trade:

(6) $X_{n}^{S}=C E T\left(E x_{n}, D_{n}\right)$ Export transformation 4

(7) $Q_{n}=\operatorname{CES}\left(D_{n}, M_{n}\right)$ Import aggregation (Armington) 4

(8) $E x_{n}=C E T^{*}\left(P n^{E}, P_{n}^{D}, D_{n}\right)$ Export Supply 4 
(9) $\mathrm{M}_{n}=\operatorname{CES}^{*}\left(P_{n}{ }^{M}, P_{n}{ }^{D}, D_{n}\right) \quad$ Import Demand

(10) $Q_{N T}=X_{N T}$ Demand for non-traded Goods

(11) $\Sigma P_{n}^{W M} * M_{n}+(1 / e) T_{F R}-\Sigma P_{n}^{W E} * E X_{n}-T R_{H}-T R_{G}=C A B$ Current Account Balance 1

Income and Saving:

(12) $Y_{H}(h)=W \Sigma L_{i}^{D}+\lambda \Sigma R_{n} K_{n}+D I V+e^{*} T R_{H}+P I N D E X^{*} T R_{G}$ Household Income 8

(13) $Y D_{H}(h)=\left(1-t_{y}\right) * Y_{H} \quad$ Household Disposable Income $\quad 8$

(14) $D I V(h)=d v r^{*} Y F_{K} \quad$ Dividends $\quad 8$

(15) $S_{H}(h)=m p s(h) * Y D_{H}(h) \quad$ Household Saving 8

(16) $Y_{F K}=(1-\lambda) \Sigma\left(R_{i} K_{i}\right) \quad$ Capital Income of Firms

(17) $Y_{F}=Y_{F K}+P I N D E X^{*} T_{G F} \quad$ Firms Total Income $\quad 1$

(18) $S_{F}=Y_{F}-t k^{*} Y_{F K}-D I V-T F_{R}$ Firms Saving

(19) $T X S_{i}=t x_{i}^{*} P_{i}^{*} X_{i}^{S} \quad$ Indirect Taxes 5

(20) $T X M_{n}=t m_{n}{ }^{*} e^{*} P_{n}{ }^{W M} M_{n}$ Taxes on Imports

(21) $T X E_{n}=t e_{n}{ }^{*} e^{*} P_{n}{ }^{E} E X_{n}$ Taxes on Exports

4

(22) $Y_{G}=t y^{*} Y_{H}+t k^{*} Y_{F K}+\Sigma T X S_{i}+e^{*} T_{R G}+\Sigma T X M_{n}+\Sigma T X E_{n}$ Government Revenue 1

(23) $S_{G}=Y_{G}-$ Pindex $* T-$ Pindex $* T-C T$ Government Saving 1

Demand:

(24) $C_{H i}=\beta_{i}^{C}{ }^{*} C T_{H} / P_{i}^{C} \quad$ Household Consumption for good $i$

(25) $C T_{H}=Y D_{H}-S_{H} \quad$ Total Household Consumption 8

(26) $I N T D_{i}=\sum a_{i j} I C_{j}$ Intermediate Demand 5

(27) $C G_{i}=\beta_{i} C T_{G} / P_{i}^{c}$ Government Consumption 5

(28) $C_{i}=C_{i}+\mathrm{CG}_{i}$ Total Consumption of Good $i$

(29) $I_{i}=\beta_{i}^{I} * I T / P_{i}^{c} \quad$ Investment

Prices:

(30) $R_{i}=\left(P_{i}^{V A} * V A_{i}-W^{*} L_{i}^{D}\right) / K_{i}$ Returns to Capital 5

(31) $P_{n}\left(1+t x_{i}\right) * x_{n}{ }^{s}=D_{n}{ }^{s} * P_{n}{ }^{D}+\left(E X_{n}\right) * P_{n}{ }^{E}$ Value of Output 4

(32) $P_{n}^{V A} * V A=\left(P_{n} * X_{n}^{s}-\Sigma\left(P_{j}^{C}\right) I C_{j i} \quad\right.$ Value of Value Added 4

(33) $P_{n}^{M}=\left(1+t m_{n}\right)^{*} e^{*} P_{n}^{W M}$ Import Price 4

(34) $P_{n}{ }^{E}=\left(e^{*} P_{n}{ }^{W E} / 1+t e_{n}\right) \quad$ Export Price $\quad 4$

(35) $P_{n}{ }^{C}=\left(P_{n} / Q_{n}\right) * P_{n}{ }^{D}+\left(M_{n} / Q_{n}\right) P_{n}$ Composite Price for Composite Goods

(36) $\quad P_{n t}{ }^{C}=P_{n t} \quad$ Price for Non Traded Goods

(37) Pindex $=\Sigma\left(\beta_{i}^{X * P i)}\right.$ Price Index

Equilibrium:

(38) $\quad \operatorname{IT}=\operatorname{sum}\left(S_{H}(h)+S_{F}+S_{G}+e^{*} C A B\right)$ Saving Investment Equilibrium 1

(39) $Q_{i}=C_{i}+I N T D_{i}+I N V_{i}$ Goods Market Equilibrium 5

(40) $L s=\Sigma\left(L_{i}^{D}\right)$ Labour Market Equilibrium 1

Total Equations 


\section{VARIABLES}

\begin{tabular}{|c|c|c|c|}
\hline \multicolumn{2}{|c|}{$\begin{array}{l}\text { Endogenous } \\
\text { Variables }\end{array}$} & \multirow{2}{*}{$\begin{array}{c}\text { Definition } \\
\text { Total Consumption of Goods }\end{array}$} & \multirow{2}{*}{$\begin{array}{c}\begin{array}{c}\text { Number of } \\
\text { Variable }\end{array} \\
5\end{array}$} \\
\hline$(1)$ & $\mathrm{C}_{\mathrm{i}}$ & & \\
\hline (2) & $\mathrm{CG}_{\mathrm{i}}$ & Public final Consumption of Goods i & 5 \\
\hline (3) & $\mathrm{CH}_{\mathrm{i}}(\mathrm{h})$ & Household h's Consumption of Goods i & 40 \\
\hline (4) & $\mathrm{CT}_{\mathrm{H}}(\mathrm{h})$ & Total Consumption of household $\mathrm{h}$ & 8 \\
\hline (5) & $\mathrm{D}_{\mathrm{n}}$ & Domestic Demand for domestically produced goods & 4 \\
\hline (6) & DIV (h) & Dividends distributed to Households from firms & 8 \\
\hline (7) & $\mathrm{EX}_{\mathrm{n}}$ & Exports of nth goods (FOB) & 4 \\
\hline (8) & $M_{n}$ & Imports of nth goods (CAF) & 4 \\
\hline (9) & $\mathrm{IC}_{\mathrm{i}}$ & Total Intermediate Consumption of Goods by $i$ th sector & 5 \\
\hline (10) & $\mathrm{ICJ}_{\mathrm{ij}}$ & Intermediate Consumption of Goods $\mathrm{J}$ by ith sector & 25 \\
\hline (11) & INTD $_{\text {I }}$ & Intermediate Demand of Good I & 5 \\
\hline (12) & $\mathrm{INV}_{\mathrm{i}}$ & Consumption of Goods by I for investment in sector i & 5 \\
\hline (13) & IT & Total Investment & 1 \\
\hline (14) & $\mathrm{L}_{\mathrm{i}}^{\mathrm{D}}$ & Labour Demand in sector $\mathrm{i}$ & 5 \\
\hline (15) & $P_{n}$ & Producer price & 4 \\
\hline (16) & $\mathrm{P}_{\mathrm{i}}^{\mathrm{C}}$ & Price of Composite goods & 5 \\
\hline (17) & $\mathrm{P}_{\mathrm{n}}{ }^{\mathrm{D}}$ & Price of domestically produced and consumed goods & 4 \\
\hline$(18)$ & $P_{n}{ }^{E}$ & Domestic price of Exports & 4 \\
\hline (19) & $P_{n}^{M}$ & Domestic Price of Imports & 4 \\
\hline (20) & $\mathrm{P}_{\mathrm{n}}^{\mathrm{VA}}$ & Value Added Price & 5 \\
\hline (21) & PINDEX & Producer price Index & 1 \\
\hline (22) & $\mathrm{Q}_{\mathrm{i}}$ & Domestic Demand for Composite Goods i & 5 \\
\hline (23) & $\mathrm{R}_{\mathrm{n}}$ & Rate of Return on capital in branch $\mathrm{n}$ & 5 \\
\hline (24) & $\mathrm{S}_{\mathrm{F}}$ & Firms Saving & 1 \\
\hline (25) & $\mathrm{S}_{\mathrm{G}}$ & Government Saving (Fiscal Deficit) & 1 \\
\hline$(26)$ & $\mathrm{S}_{\mathrm{H}}(\mathrm{h})$ & Saving of Household $\mathrm{h}$ & 8 \\
\hline (27) & $\mathrm{TXE}_{\mathrm{I}}$ & Taxes on Imports of $n$th sector & 4 \\
\hline (28) & $\mathrm{TXM}_{\mathrm{i}}$ & Taxes on Exports of $n$th sector & 4 \\
\hline (29) & $\mathrm{TXS}_{\mathrm{I}}$ & Indirect taxes on $i$ th sector production & 5 \\
\hline (30) & $\mathrm{VA}_{\mathrm{I}}$ & Value Added of sector i & 5 \\
\hline$(31)$ & $\mathrm{X}_{\mathrm{i}}^{\mathrm{s}}$ & Production of $i$ th sector & 5 \\
\hline (32) & $\mathrm{Y}_{\mathrm{H}}(\mathrm{h})$ & Total Income Household h & 8 \\
\hline (33) & $\mathrm{YD}_{\mathrm{H}}(\mathrm{h})$ & Disposable income of $\mathrm{h}$ Households & 8 \\
\hline (34) & $\mathrm{Y}_{\mathrm{F}}$ & Firms total income & 1 \\
\hline (35) & $\mathrm{Y}_{\mathrm{G}}$ & Government Revenue & 1 \\
\hline (36) & $\mathrm{YK}_{\mathrm{F}}$ & Firms Capital Income & 1 \\
\hline (37) & $\mathrm{W}$ & Wage rate & 1 \\
\hline & Total Enc & us Variables & 214 \\
\hline
\end{tabular}

$18 * 5+8 * 1+10 * 8+9 * 4=90+8+80+36=214$.

\begin{tabular}{llc}
\hline Exogenous Variables & & \\
\hline $\mathrm{CAB}$ & Current Account Balance & 1 \\
$\mathrm{CT}_{\mathrm{G}}$ & Government final consumption & 1 \\
$\mathrm{e}$ & Exchange Rate & 1 \\
$\mathrm{~K}_{\mathrm{n}}$ & Branch I's Capital Stock & 3 \\
$\mathrm{~L}^{\mathrm{S}}$ & Total Labour Supply & 3 \\
$\mathrm{P}_{\mathrm{n}}{ }_{\mathrm{WE}}$ & World Price of Exports & 4 \\
$\mathrm{P}_{\mathrm{n}}{ }^{\mathrm{W}}$ & World Price of Imports & 4 \\
$\mathrm{~T}_{\mathrm{FR}}$ & Firms transfers to the rest of world & 1 \\
$\mathrm{~T}_{\mathrm{GF}}$ & Government transfers to Firms & 1 \\
$\mathrm{~T}_{\mathrm{GH}}(\mathrm{h})$ & Government Transfers to Households & 8 \\
$\mathrm{~T}_{\mathrm{RG}}$ & Foreign transfer payments to the Government & 1 \\
$\mathrm{~T}_{\mathrm{RH}}(\mathrm{h})$ & Foreign transfers to Households & 8 \\
Total Exogenous Variables & $\mathbf{3 6}$ \\
\hline
\end{tabular}




\section{SYMBOLS}

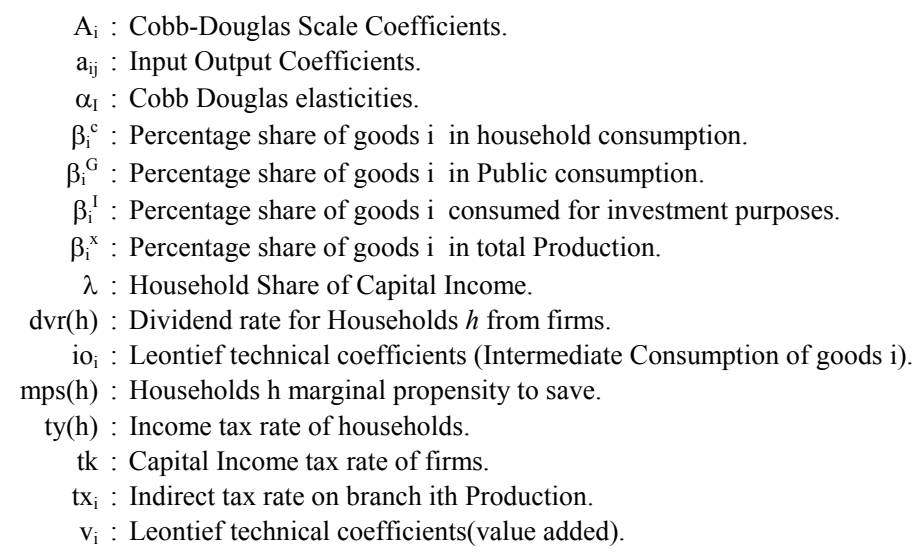

\section{REFERENCES}

Amjad, R., and A. R. Kemal (1997) Macroeconomic Policies and their Impact on Poverty Alleviation in Pakistan. The Pakistan Development Review 36:1.

Decaluwe, B., M. C. Martin, and M. Souissi (1996) Ecole PARADI de modelisation de politiques economiques de development. Quebec: Universite Laval.

Iqbal, Z., and R. Siddiqui (1999) The Impact of Structural Adjustment on Income Distribution in Pakistan: A SAM Based Analysis . Pakistan Institute of Development Economics, Islamabad. (MIMAP Technical Report No. 2.)

Mahmood, Zafar (1999) Pakistan Conditions Necessary for the Liberalisation of Trade and Investment to Reduce Poverty. Unpublished Research Paper.

Nasir, Z. M. (1999) Poverty and Labour Market Linkages. Pakistan Institute of Development Economics, Islamabad. (MIMAP Technical Report).

Siddiqui, Rizwana, and Zafar Iqbal (1999) Social Accounting Matrix of Pakistan for 1989-90. Pakistan Institute of Development Economics, Islamabad. (Research Report No. 171.)

Siddiqui, Rizwana, and Zafar Iqbal (1999a) The Impact of Tariff Reduction on Functional Income Distribution of Households: A CGE Model for Pakistan. Presented in Regional Workshop on Modeling Structural Adjustment and Income Distribution: CGE Framework, May 16-17.

Thorbecke, E. (1991) Adjustment, Growth and Income Distribution in Indonesia. World Development 19: 11 1595-1614.

Tilat, A. (1996) Structural Adjustment and Poverty: The Case of Pakistan. The Pakistan Development Review 35:4 911-926.

White, H. (1997) The Economic and Social Impact of Adjustment in Africa: Further Empirical Analysis. Unpublished Paper. 


\section{Comments}

The subject study uses economy-wide framework Computable General Equilibrium (CGE) based on Social Accounting Matrix to analyse the effects of Structural Adjustment Policies on income distribution in Pakistan. There being three channels through which these adjustment policies affect income distribution namely relative price effect, asset price effect and portfolio shift effect, the study incorporates the relative price effect only bypassing the other equally important channels.

The focus of the study is on measuring the impact of 80 percent reduction in tariffs on industrial products which is analysed using Social Accounting Matrix of 1989-90 which is the latest available in Pakistan. The CGE Model is of a neoclassical nature which contains 6 blocks and about two hundred equations. The value of exchange rate which serves as numeraire is set equal to one. The economic blocks are the production sector, labour demand, foreign trade sector, income, saving and consumption sector, household sector, firm sector and the government sector, which are 7 in number and not 6 as is claimed in the beginning of the study.

The study, when examined critically in terms of its basic structure, approach, methodology and conclusions, turns out to be of a far lesser use as a tool for policy formulation, as compared to the claims of the authors.

The basic problem with the study relates to its failure to identify the different parameters of the study in precise terms e.g. it focuses on 80 percent tariff reduction on industrial products. However, it does not identify what are the benchmark tariffs and what are the final levels of tariffs after 80 percent reduction. The study also does not identify the composition of industrial products such as raw materials for consumer goods, raw materials for capital goods or final industrial products like machinery etc. It was desirable for proper understanding of the subject that the classification of industrial products according to STIC System or itemwise specifications in line with Pakistan's tariff schedule were given.

The study is based on Social Accounting Matrix for the year 1989-90 which is fairly outdated and does not reflect some of the basic transformations in the economy of Pakistan experienced during the last one decade. However, SAM 1989-90 could be upgraded by using plausible assumptions about the real growth rate of the major sectors of Pakistan's economy and the inflation rates and that could serve as a better data base for analysing the effects of tariff changes on the income distribution. Such an upgradation of the SAM was undertaken in 1999-2000 by the Tax Policy Unit of the Central Board of Revenues (CBR) and was quite useful for studying the impact of tax policy changes on revenues, prices, etc.

The relevance of the neo-classical nature of the CGE Model can be questioned one the premise that economies of the most of the developing countries including Pakistan suffer from basic distortions and imperfections which reflect major departure from the basic structure and assumptions of CGE Neo-classical Models. 
The results of the study are counter-intuitive and contradictory. For example, one of the conclusions of the study is that low growth in domestic output and decline in consumption has resulted in a sharp increase in the exportable surplus but the very next conclusion states that the decline in import price has increased the demand for industrial goods which is related in a positive effect on consumption and composite demand. Obviously the two conclusions are contradictory in nature.

Another contradictory result of the study relates to the behaviour of investment and income growth. According to the study, 80 percent reduction in tariffs on industrial products increases investment in all the sectors, but, the income declines at the same time. This result contradicts the basic principles of production and growth theory which establishes a positive co-relation between investment and real growth in an economy.

The study correctly concludes that reduction in tariffs brings about significant losses in government revenues but the study fails to provide any quantitative estimates of such losses. The estimation of revenue losses in relatively precise terms should not be difficult once a CGE Model is deployed for analytical purposes.

The study establishes positive directions in the distribution effects of tariff reduction, as the negative impact on household consumption is shown to be disproportionately high for higher income groups coming from a higher income decline as compared to the income decline of lower income groups. This conclusion is not convincing because the linkages between tariff reduction and household consumption, income distribution are not clearly established. Once investment increases as the study observes, it is natural to expect that this will be adding to the income of high income group households and is likely to improve their share in the distribution as well.

The study fails to analyse the impact of tariffs on the level of protection specially the changes in Effective Protection Rates (EPRs) and Domestic Resource Cost (DRC) of the different industrial sector on account of tariff reduction. The CGE Model could be modified to diagnose this aspect of industrial growth in Pakistan.

One of the major problems currently faced by the industrial sector of Pakistan relates to its increasing non-competitiveness in the world economy resulting from lower protection following the policy of reducing tariffs on regular intervals under IMF (ESAF/EFF), World Bank and WTO commitments and pressures. In other words, lower tariffs are one of the important factors leading to growing number of sick units as well as the industrial stagnation being experienced in Pakistan. The study fails to incorporate the protection effect of tariff reduction on industrial output and income distribution.

Central Board of Revenue,

Aqdas Ali Kazmi Islamabad. 